\title{
Justice, gender and the politics of multiculturalism
}

\author{
Sarah Song \\ Cambridge University Press, Cambridge, 2007, 212pp., £14.99, \\ ISBN: 978-0521874878
}

Contemporary Political Theory (2009) 8, 368-370. doi:10.1057/cpt.2008.58

Arguably, the greatest recent contributions to the (somewhat exhausted) political philosophy of multiculturalism have come from feminists. The debate was famously sparked by Susan Okin's warning that multicultural accommodation could legitimize and aggravate the oppression of women within traditional, cultural and religious groups (Okin, 1999). Critics retorted that the 'internal minorities' objection, as articulated by Okin, tended to assume that minorities were essentially and comprehensively illiberal, and majorities the paragons of liberal egalitarians values - the very ethnocentric assumptions that had made accommodation a demand of justice in the first place. Soon, however, the debate moved on from its rather simplified, early formulations (gender equality vs cultural rights) and went on to illuminate areas that the academic discussion of multiculturalism had bizarrely left unexamined. Feminist contributions over the last decade or so have made three crucial contributions (Shachar, 2001; Deveaux, 2007; Phillips, 2007; Chambers, 2008).

First, in line with the critical project of feminist theory, they have been sensitive to the way in which 'cultures' do not pre-exist, but are largely shaped by social interaction, are far less homogenous, normative, static and coherent than political theorists have assumed, and cannot be understood through the choice/chance 'luck egalitarian' paradigm. Second, feminists have shown how gender hierarchies structure all cultures, Western and non-Western, and explored the troubling fact that the status of women seemed to be at the heart of most cultural conflicts in the West. Third, feminists have suggested that such conflicts are not only animated by concerns about justice but also about more strategic political concerns on the part of both majority and minority representatives. Methodologically, the new feminists have exploited the rich area of comparative law theory (and cases such as traditional marriages, female genital cutting, veiling, honour killings, tribal inheritance rights, sex trafficking) and critically highlighted the role played both by the stereotyped culture attributed to non-Western minorities and the less visible, taken-for-granted, gendered cultural assumptions of majority groups in maintaining and justifying the silencing of women. Because cultural norms are contingent and variable, manipulated by elites, and bear an uncertain relationship to 
liberal ideals of autonomy and equality, feminists have usually advocated deliberative/democratic, rather than (or in addition to) legalistic/liberal solutions to cultural conflicts.

Sarah Song's Justice, Gender and the Politics of Multiculturalism offers a thoughtful and distinguished contribution to this burgeoning field. Her book combines the strengths of Anne Phillips' Multiculturalism without Culture and Deveaux's Gender and Justice in Multicultural Liberal States. She provides a lucid re-appraisal of the state of multicultural political theory, supported by incisive, nuanced analyses of US legal cases about 'cultural defence' arguments in criminal law, tribal membership and Mormon polygamy, and she eloquently shows the difference that deliberative politics can make to political practice and political theory.

Developing a 'constructivist' account of cultures sensitive to the historical shaping of cultural norms through social interaction, Song powerfully shows the limitations of the standard view that minority cultures are intrinsically more patriarchal than the majority (Western) culture. In particular, she highlights three ways in which gender statuses have been shaped by inter-cultural interaction. The first she calls the congruence effect, whereby minority cultural norms are given credibility in courts not out of respect for 'difference' but because they are familiar to the majority culture. Such is the case for 'cultural defense' arguments in honour killings, which tend to invoke standard (and cross-cultural) conventions of gender differences, conveying for women a particular stereotype of passivity and for men a meaningful context for violent actions, and serving to diminish both the severity of men's actions and the agency and responsibility of women themselves. The second effect is the boomerang effect, where the toleration of patriarchal norms and practices within minority cultural communities may establish dangerous precedents for progress towards gender equality within wider society. The third effect is the diversionary effect, whereby the majority's condemnation of minority practices serves to divert attention from its own gender hierarchies.

Like many multicultural feminists, Song tends to overplay the parallels between gender oppression in Western and non-Western cultures, but she is at her best in demonstrating how the stigmatization of 'alien' practices (such as Mormon polygamy) served both to divert attention from the most progressive practices of the Mormon community (easy divorce for women, early political rights) and to entrench the strict division of labour of the monogamous, heterosexual Christian family. In line with recent feminist contributions, Song powerfully shows that it is oppressive practices, rather than culture itself, that are the problem; and that what drives the politics of accommodation in the West is not necessarily justice but, rather, the dynamics of congruence, imposition and diversion. 
To counteract these, Song advocates what she calls 'rights-respecting accommodationism', whereby differential treatment of minority members may be justified provided (i) there is a context of historical or present injustice, discrimination or bias, (ii) accommodation furthers a fundamental interest of minority members, and (iii) accommodation does not infringe basic rights or other compelling governmental interests (to use the phrase of the Religious Freedom Restoration Act from which Song takes her cue). Song then suggests that only deliberative practices can identify the relevant interests at stake in the tricky balancing act involved in mutual cultural contestation.

Of this ambitious attempt to combine legal, political and philosophical reflections, the latter are perhaps the least innovative: the status of rights in Song's theory is somewhat unclear, and slightly question-begging. But her analyses of the legal cases are thought provoking and are in themselves excellent contributions to multicultural political theory. With this (and other recent similar) work, multicultural thinking has moved on a generation, and transcended the sterile debate between universalists and multiculturalists. Too many Western political theorists have tended to judge their societies according to their (universal) ideals, and those of others according to their (cultural) practices. What Song shows is that liberals' confrontation with the cultures of 'alien' minorities brings to light the cultural (and in particular gendered) way in which liberal ideals such as autonomy and equality have been interpreted in Western societies. Those ideals need to be rescued, re-interpreted and rehabilitated against the cultural relativism of some multiculturalists - but only the kind of contextual cum normative theory of which Song offers a fine example here is well-equipped for this particular challenge.

\section{References}

Chambers, C. (2008) Sex, Culture, and Justice: The Limits of Choice. Philadelphia, PA: Penn State University Press.

Deveaux, M. (2007) Gender and Justice in Multicultural Liberal States. Oxford: Oxford University Press.

Okin, S.M. (1999) Is Multiculturalism Bad for Women?. Princeton, NJ: Princeton University Press.

Phillips, A. (2007) Multiculturalism without Culture. Princeton, NJ: Princeton University Press.

Shachar, A. (2001) Multicultural Jurisdictions: Cultural Differences and Women's Rights. Cambridge: Cambridge University Press.

Cécile Laborde

University College London, London, UK 